\title{
Strategy implications of world gas market dynamics
}

\author{
Ruud Weijermars \\ Alboran Energy Strategy Consultants \& Department of Geotechnology, Delft University of Technology, Stevinweg 1, Delft 2628CN, The Netherlands
}

\section{A R T I C LE I N F O}

\section{Article history:}

Received 8 November 2011

Accepted 8 November 2011

Available online 16 December 2011

\section{A B S T R A C T}

Global trends - past and future - of world natural gas consumption, production, reserves, and prices are highlighted here analyzing the BP Statistical Review of World Energy 2011, the BP Energy Outlook 2011, and the latest natural gas data from the world's major energy agencies. Growing demand and declining gas-reserve- replacement ratios support market model predictions of rising natural gas prices.

(C) 2011 Published by Elsevier Ltd.

\section{BP energy outlook}

Projections of future energy use based on long-term energy trends for the period 2010-2030 have been released by BP for external use, for the first time, in its Energy Outlook 2011 [1]. The starting point of the BP Energy Outlook has been BP's own Statistical Review of World Energy 2011 [2], which is published every year in June. BP CEO Bob Dudley states it is the company's responsibility to make important information and energy analysis available for public debate, because energy and its relation to economic development on one side, and to climate change on the other, are vital issues to all of us. Around the world, there is a lively and important conversation taking place on the choices that face us all - as consumers, producers, investors and policy-makers. BP's Energy Outlook is but one projection, and reflects the company's 'to the best of our knowledge' assessment of the world's likely energy path from today's vantage point. This review complements BP's statistics and trend projections with authoritative gas data from the US Energy Information Administration (which includes data from the International Energy Agency). BP uses European metrics (bcm) in its Statistical Review and American units (Bcf/d) in its

E-mail address: R.Weijermars@TUDelft.nl.
Energy outlook, which explains why both units appear in this report review.

\section{Gas trade}

Fig. 1 outlines the world's major traded gas flows between continents and regions for 2010 [2]. The global trade of natural gas increased $10.1 \%$ in 2010 . World gas trade is still dominated by nearly $60 \%$ pipeline gas importation. Pipeline exports grew by just $5.4 \%$, led by growth in Russian exports. Europe and Eurasia together still account for roughly two-thirds of the global trade volume of pipeline gas imports. However, LNG supplies have risen much faster than pipeline imports. LNG shipments already accounted for $40.5 \%$ of global gas trade importation volumes in 2010. LNG exports are dominated by supplies from the Middle East region. Qatar is the world's single largest LNG supplier [2]. A $22.6 \%$ increase in 2010 LNG shipments was driven by a $53.2 \%$ increase in Qatari shipments. Among LNG importers, the largest volumetric growth was in South Korea, the UK and Japan. Trinidad-Tobago continues to supply LNG to markets at both sides of the North Atlantic basin.

\section{Gas consumption}

World natural gas consumption grew by $7.4 \%$ in 2010 (Fig. 2a), with above-average growth in all regions but the Middle East. Consumption growth was above average in all regions - the most rapid increase since 1984 - except the Middle East. The US had the world's largest 2010 increase in consumption (in volumetric terms), rising by $5.6 \%$ to a new record high [2]. Russia and China also registered large increases - the largest volumetric increases in the country's history in each case. Consumption in other Asian countries also grew rapidly in 2010 $(+10.7 \%)$, led by a $21.5 \%$ increase in India.

\section{Gas production}

The world's production of natural gas increased by $7.3 \%$ in 2010 (Fig. 2b), recording the largest increase since 1984 [2]. Natural gas production continues to grow in every world region, except Europe - where decline rates at mature fields are reversing the production gains seen in previous decennia [3]. Production growth was above average in all regions; Russia recorded the largest production gains in absolute increment. Domestic production grew rapidly in Qatar $(+30.7 \%)$, Russia $(+11.6 \%)$, and the US $(+4.7 \%)$. The US remains the world's largest gas producer, with supply of unconventional gas continuing to grow despite weak North American natural gas prices, trading at record discounts to crude oil in 2011. Canadian gas production saw the world's largest 


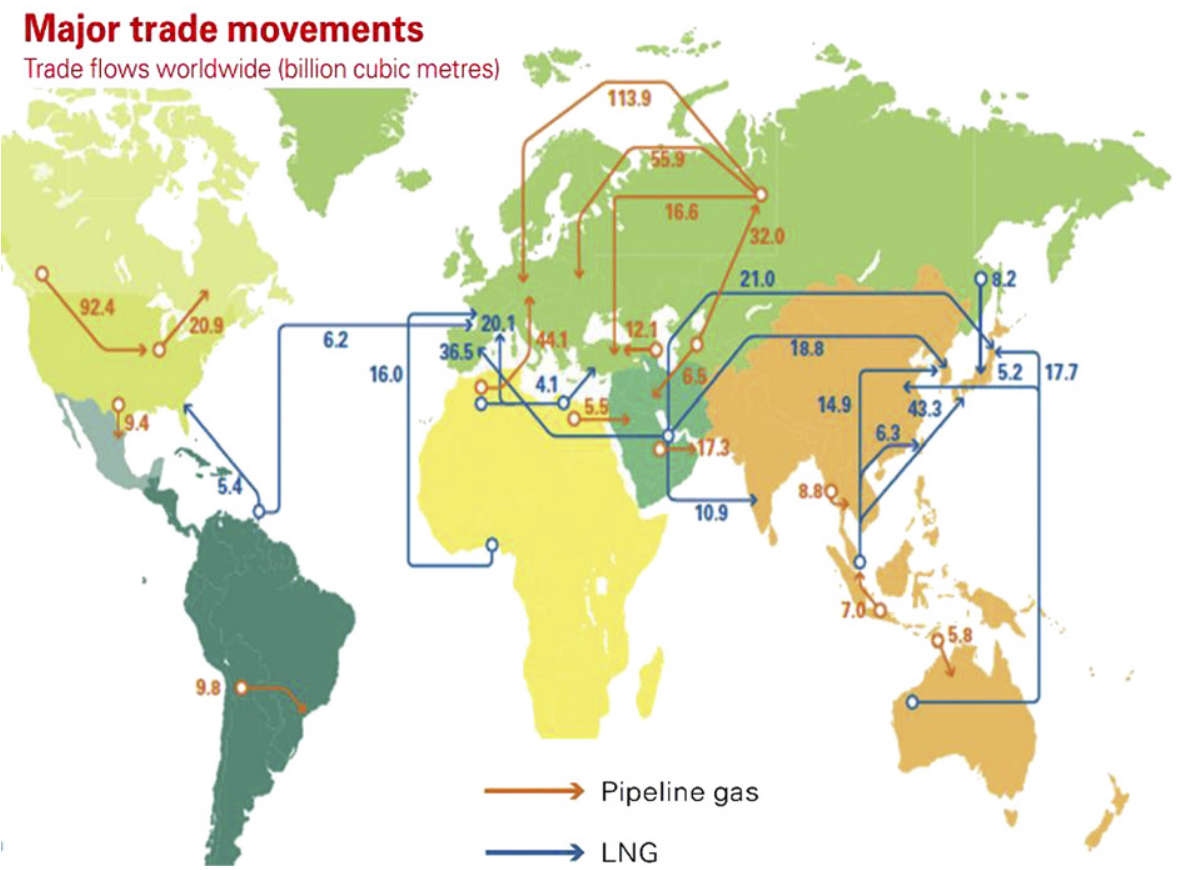

Fig. 1. Major gas trade flows (bcm) between world regions in 2010 [2].

decline, falling in 2010 for a fourth consecutive year, as exports to the US are replaced by the US domestic gas production.

\section{Conventional gas reserves}

World conventional gas reserves (including tight gas) have expanded between 1990 and

a

$$
\text { Consumption by region }
$$

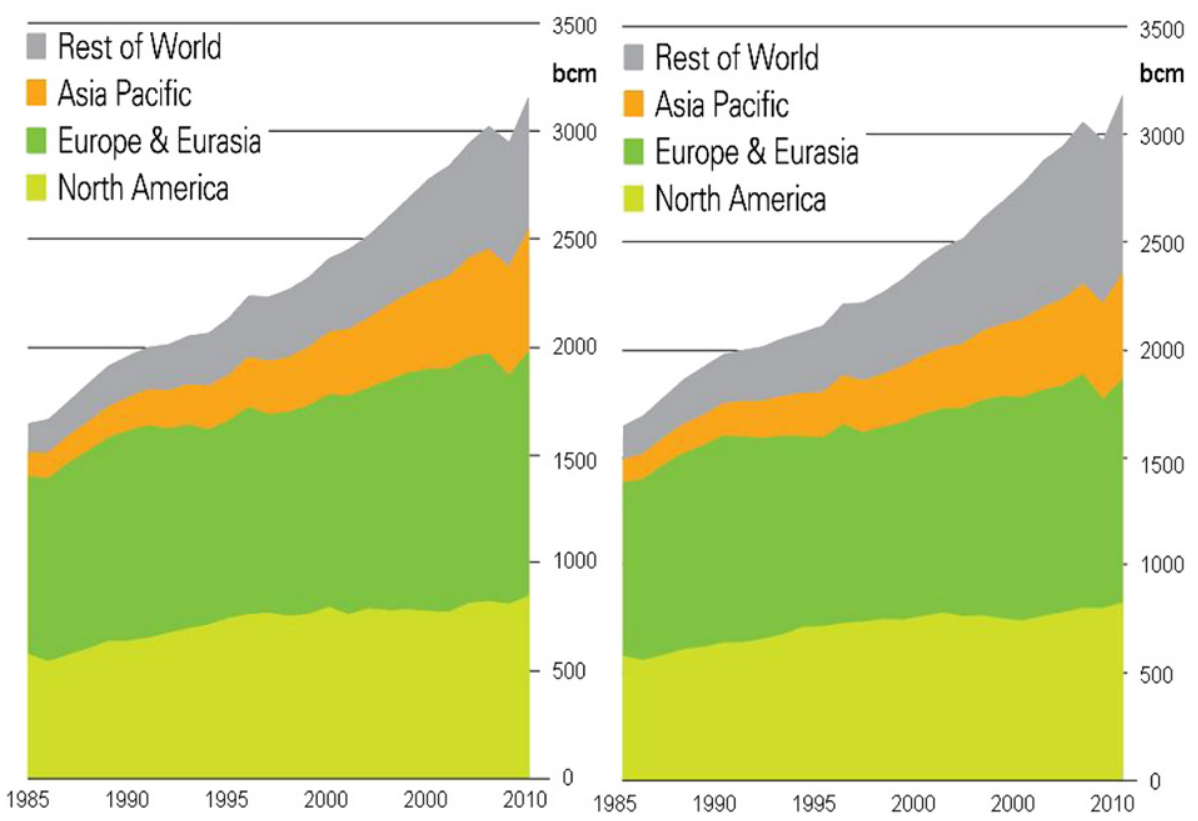

Fig. 2. a: Growth in world annual gas consumption $(\mathrm{bcm})$ by region. b: Growth in annual gas production (bcm) by region [2]. years of global production, as follows from the world average gas reserve replacement ratio $(\mathrm{R} / \mathrm{P})$ of 58.6. The R/P ratios declined for each region distinguished in Fig. $3 b$, driven by rapidly rising consumption which outpaces the regional production growth. The Middle East holds the highest R/P ratio, but has been rapidly declining from over 600 in the early 1980 s to less than 200 in recent years (Fig. 3b).

\section{Gas consumption to 2030}

In BP's Energy Outlook [1] natural gas consumption is projected to account for the fastest growing fossil fuel globally to 2030, but growth slows relative to its historic growth (Fig. 4a). Over the past two decades, the compounded growth of natural gas demand by $2.4 \%$ annually is twice as fast as oil demand growth. The absolute volume of global gas demand amounts to $300 \mathrm{Bcf} / \mathrm{d}$ in 2010 and is set to grow by $8.4 \mathrm{Bcf} / \mathrm{d}$ per year. On an energy equivalent basis, global gas consumption equals to about 50 million bbl/ d of oil.

Gas consumption growth is modest in OECD markets ( $1 \%$ p.a.), particularly in North America. Efficiency gains and low population growth keep industrial and residential sector gas growth at $0.5 \%$ p.a. across the OECD. Growth is concentrated in the power sector. The non-OECD countries account for $80 \%$ of the global rise in gas consumption, with volume growth averaging 3\% p.a. to 2030 . Non-OECD gas use is driven by economic growth, accompanying industrialization, industrial policy, the power sector and the development of domestic resources. Gas demand grows fastest in non-OECD Asia (4.6\% p.a.) and the Middle East (3.9\% p.a.) over 2010-2030. The power sector accounts for $44 \%$ of this growth as domestic gas and imports in some countries displace oil burning. Petrochemical industries are contributing to the projected $3.2 \%$ p.a. growth in industrial gas use.

Asia accounts for the world's largest gas consumption increase to 2030 [1]. China drives $56 \%$ of the region's volumetric consumption growth. Gas consumption grows rapidly in China (7.6\% p.a.) to a level of gas use in 2030 of $43 \mathrm{Bcf} /$ day, which is comparable to that of the European Union today of $47 \mathrm{Bcf} /$ day. But because of the low starting point, the gas share in China's primary energy mix remains relatively low at only $9 \%$ in 2030 versus 4\% in 2010.

The Middle East has the world's second largest gas consumption increase to 2030 [1]. The region's share in global consumption is expected to expand from $5 \%$ in 1990 and $12 \%$ in 2010 to $17 \%$ in 2030 . Its relative share in global production firms up from 15\% in 2010 to $19 \%$ in 2030. 


\section{a Distribution of proved reserves in 1990,2000 and 2010}
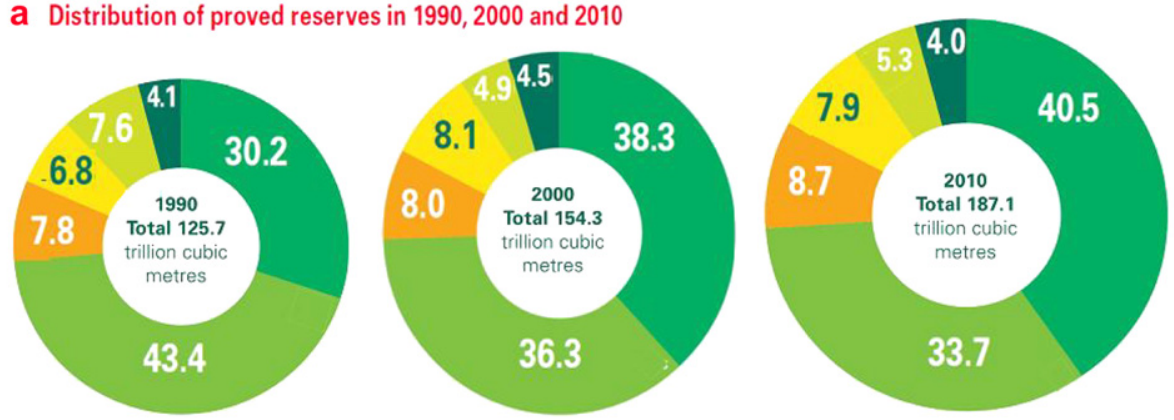

Middle East $\quad$ Europe \& Eurasia

Asia Pacific 1 Africa

North America

S. \& Cent. America

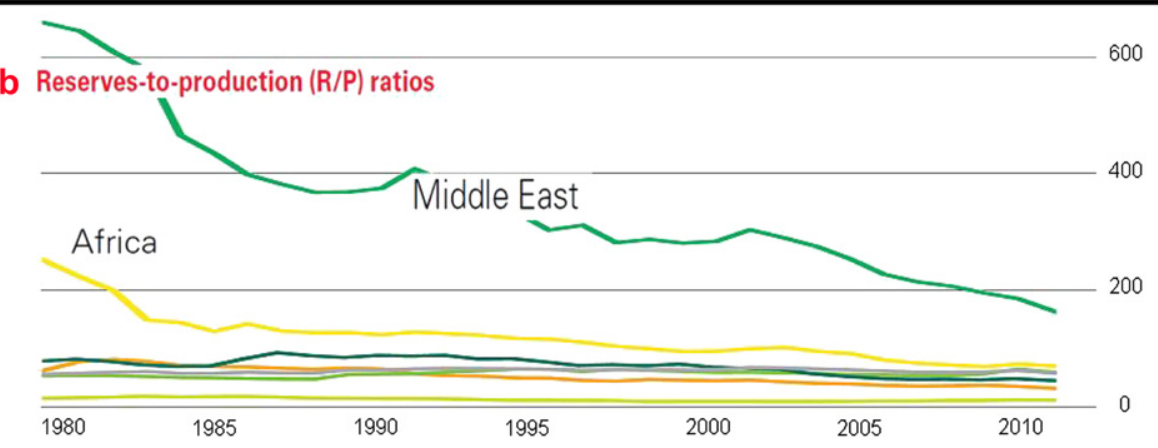

Fig. 3. a: Conventional gas reserves for the world have steadily increased between 1990, 2000 and 2010 . Segment size of world region scaled by percentage of global gas reserves [2]. b: Decline of R/P ratios for all world regions is lead by Middle East regression [2].

Brazil, Russia, India and China (BRICs) contribute $40 \%$ to the total non-OECD gas consumption increment [1]. Gas use grows most rapidly in China (7.6\% p.a.), India ( $4.7 \%$ p.a.) and Brazil (4.6\% p.a.), facilitated by rising domestic production and imports.
Industrial activity accounts for $50 \%$ and the power sector for $29 \%$ of the gas consumption growth. Elsewhere in the non-OECD, gas consumption expands most strongly in power ( $2.9 \%$ p.a.) and industry (2.0\% p.a.). Residential, commercial and other sector growth

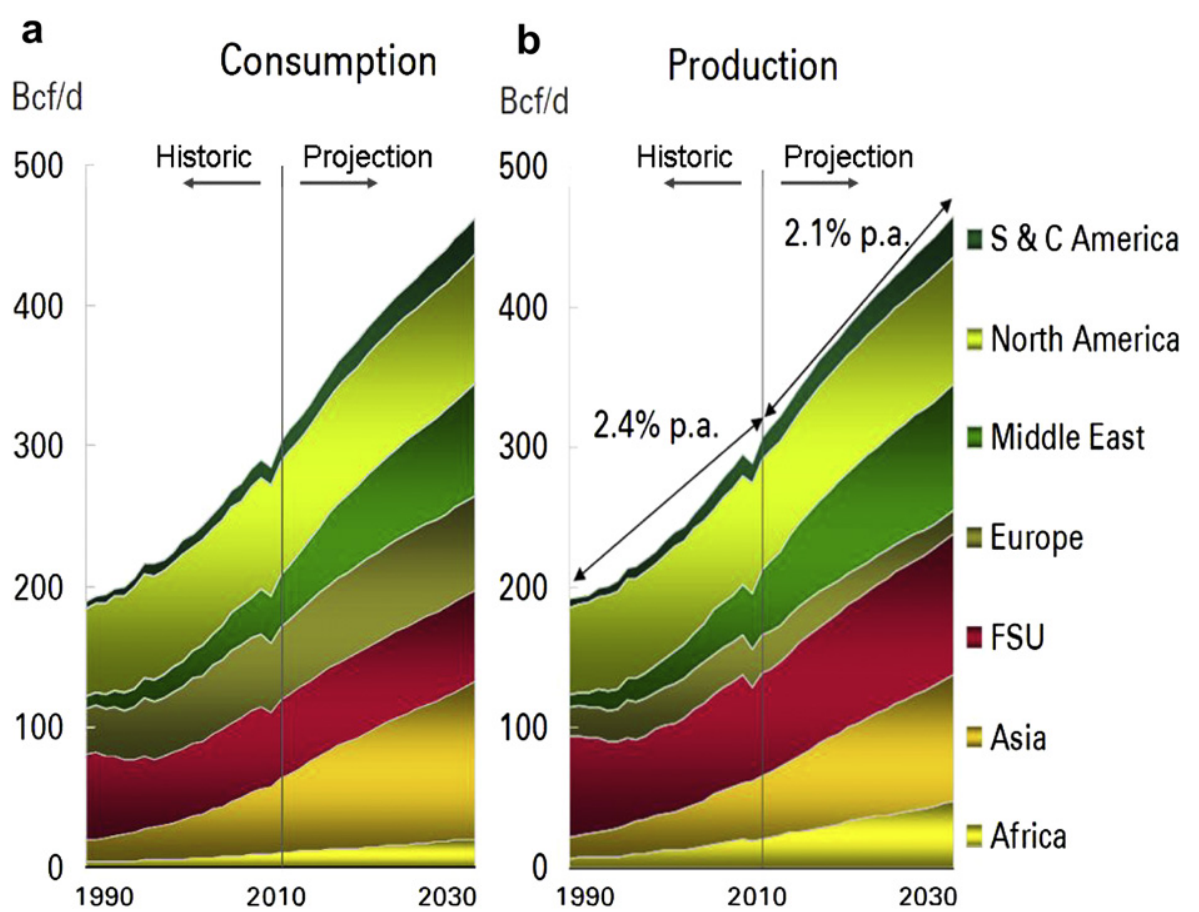

Fig. 4. a: Growth in world daily gas consumption (bcf/day) by region. b: Growth in daily gas production (bcf/day) by region [1]. is modest $(0.6 \%$ p.a. $)$, primarily due to expected efficiency gains in FSU countries outside Russia ( $-0.6 \%$ p.a.).

Globally, natural gas is the fastest growing fossil fuel in power generation and grows its share in power generation from fossil fuels grows from $30 \%$ today to $37 \%$ in 2030 [1]. Its share in total electricity generation increases from $20.5 \%$ to $22 \%$. Growth rates of gas use in the power sector are fast $(2.6 \%$ p.a. $)$ and second fast is gas use in industry ( $2 \%$ p.a.) consistent with historic patterns. Natural gas is favored over coal for power generation as it has only half the $\mathrm{CO} 2$ emissions of conventional coal power generation and near zero sulphur emissions. Gas is expected to displace coal in power generation across the OECD due to rising carbon prices, permitting constraints for new plant approvals and mandates. Coal displacement is likely to be strongest in Europe, where regulation is most advanced. $\mathrm{BP}$ expects global $\mathrm{CO}_{2}$ emissions to continue rising, along with energy import dependence in many key consuming regions. While trebling from today's level, compressed natural gas (CNG) use in transport remains confined to $2 \%$ of global transport fuel demand in 2030.

\section{Gas production and reserves to $\mathbf{2 0 3 0}$}

The world had 6621 Tcf of proved gas reserves in 2009, sufficient for 63 years of production at current levels [1], but in 2010 this had already dropped to 58.6 years [2]. Although gas production grows in every region except Europe, the increasing demand continues to outpace any growth in global reserves. With declining conventional fields, Europe's gas import requirement is likely to double by 2030 . Unconventionals remain to be appraised in detail globally, and could add another 30 years of natural gas supply worldwide. Absent another technological breakthrough, significant unconventional gas production in Europe is not expected until around 2020.

The US has, by painstakingly searching for new ways to optimize unconventional gas recovery technologies over the past 30 years, paved the way for the worldwide development of shale gas. US Energy Information Administration data [4] show that the turnaround in US gas production decline occurred in the 1990s, when tight gas and CBM halted a further decline in the US natural gas production (Fig. 5a), underpinned by a steep rise in US proved gas reserves over the past decade. The growth of US gas reserves is entirely accounted for by non-traditional or unconventional gas reservoirs (Fig. 5b). In particular, the development of tight gas plays has been very successful. As a result, US gas production can still provide for nearly $90 \%$ of total US gas demand and the remainder is largely covered by foreign pipeline gas, from neighboring Canada and Mexico. Shale gas 
a

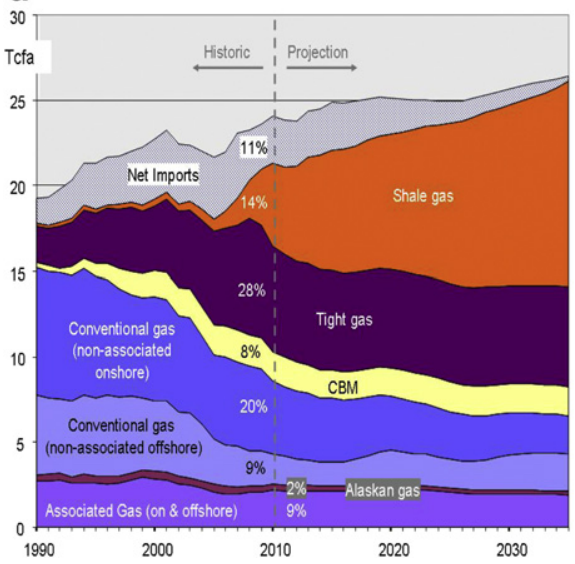

b

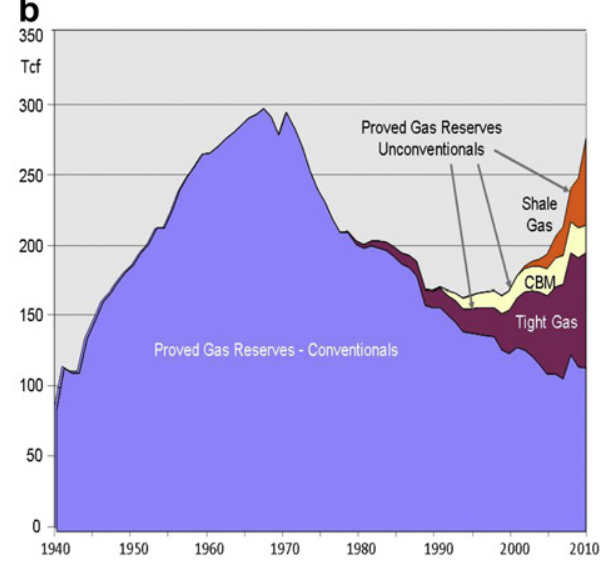

Fig. 5. a: US natural gas production separated into reservoir type. Tight gas accounts for $28 \%$ of US 2010 total gas consumption. Shale gas accounts for $14 \%$, but is DOE/EIA expects this to have tripled by 2035 . US gas net imports will be displaced further by growth in the domestic shale gas production [4]. b: The sharp upturn in reported US proved gas reserves over the past decade is entirely due to the development of unconventional gas resources. Total proved reserves graphed are derived from DOE/IEA annual totals [5]. CBM reserves are reported since 1989 [6]. Shale gas reserves have only been separated by EIA since 2007 [7] and have been estimated for the earlier part of this decade. Tight gas reserves are not reported separately by the EIA - the portion of proved tight gas reserves shown is prorated in this study based on EIA production data.

and coal bed methane (CBM) are forecast to account for $57 \%$ of North American gas production by 2030 and could make LNG exports economically viable.

Outside North America, unconventionals are likely to play a growing role in the future. The ability to overcome technical and regulatory hurdles will determine their pace of development. Despite North America's continued growth in gas production, other regions replace faster the North American share in the global gas production total, its share declines from 26\% in 2010 to $19 \%$ in 2030 [1]. Gas production in the Former Soviet Union States and in Africa grows strongly to meet export demand. Asia accounts for the world's largest production increments. In China, gas production is expected to grow $6 \%$ per year. Domestic CBM and shale gas are likely to contribute $41 \%$ to this growth, but still leave a rising need for gas imports in China.

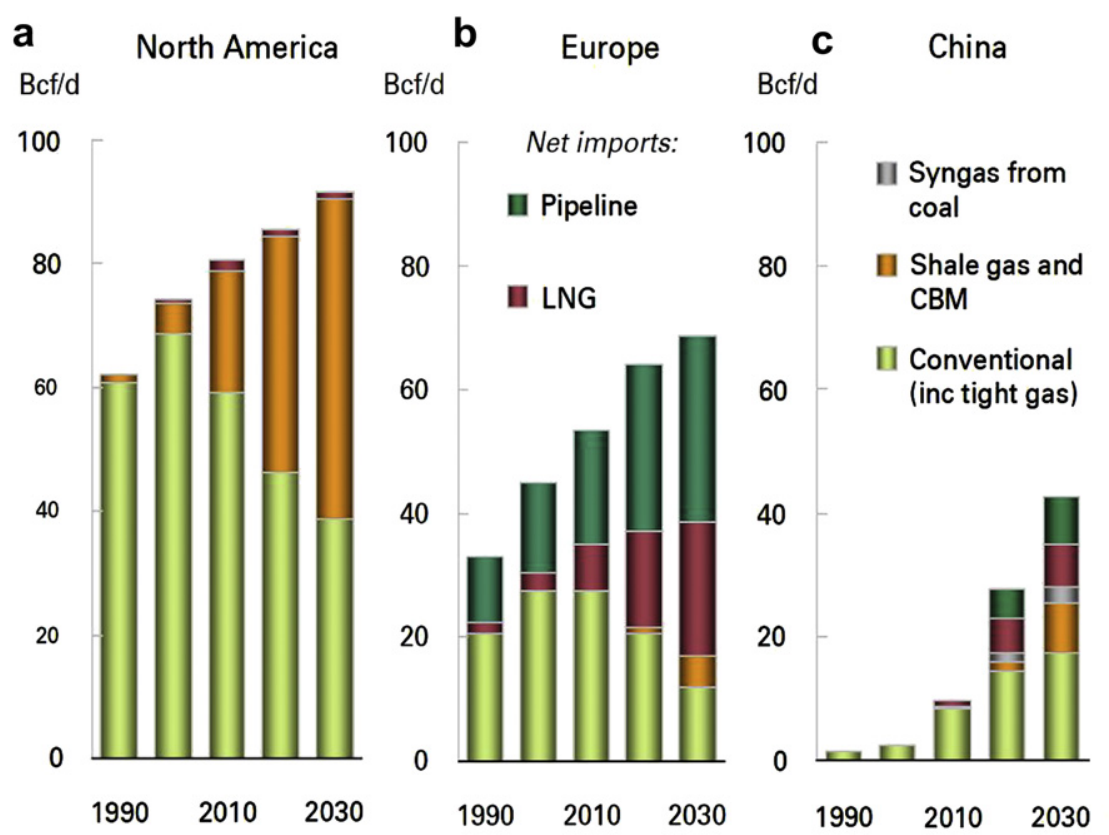

Fig. 6. a-c: Two decades (1990-2010) of historic gas production sources and imports (pipeline \& LNG) extrapolated for the next twenty years (2011-2030). a: North America by 2030 will source half of its gas from shales and coal beds, with only minor LNG imports. b: Europe has $10 \%$ of its gas supply from indigenous shale gas and CBM in 2030 , and a hefty $70 \%$ imports from outside the Eurozone (50/50 divided between LNG and pipeline imports). c: China has the steepest gas production growth rate [1].

\section{LNG trade to 2030}

LNG supply is projected to grow $4.4 \%$ p.a. to 2030 [1], more than twice as fast as total global gas production ( $2.1 \%$ p.a.). Its share in global gas supply increases from $9 \%$ in 2010 to $15 \%$ in 2030 . Demand is driven by Europe $(5.2 \%$ p.a., $36 \%$ of the global increment) and nonOECD Asia (8.2\% p.a., also $36 \%$ of the increment). In Europe, the share of LNG in total imports expands from $30 \%$ in 2010 to $42 \%$ in 2030 (Fig. 6). In non-OECD Asia, 74\% of the gas demand growth for LNG is from China and India.

The expansion of LNG trade occurs in several stages [1]. The first LNG expansion stage (2009-2011) is predominantly from the Middle East and adds $10 \mathrm{Bcf} /$ day (44\%) of LNG. This overhang will dissipate as demand for LNG grows and the next significant wave does not occur until 2015. Half of the $10 \mathrm{Bcf} /$ day (29\%) growth in the period $2015-2017$ is from new Australian LNG projects. Middle East net LNG exports could decline after 2020 as regional import growth outweighs output growth from traditional exporters. Australia therefore overtakes Qatar as the world's largest LNG exporter around 2020. The phase to 2030 is largely determined by rising LNG demand, with $41 \%$ of supply coming from Africa.

\section{Historic gas prices}

Natural gas prices are subject to regional market dynamics and may differ considerably in the world's major gas markets (Fig. 7). The oil-indexing of the Continental European gas prices ensures that these rise in step with the recovery of the global oil prices [8]. The European and US gas markets in effect have become decoupled, which may result in a large price differential between these two major gas markets [9]. Since the onset of the Great Recession in 2008, natural gas prices in the various regional gas markets have maintained distinct price levels (Fig. 7). The average Japanese 2010 LNG price was nearly $\$ 11 / \mathrm{Mcf}$, long term contract gas deliveries in Continental European fetched $\$ 8 /$ Mcf, the UK spot gas price at the National Balance Point was about $\$ 6.50 / \mathrm{Mcf}$, and the US Henry Hub reference spot gas price averaged \$4.40/Mcf [2]. In November 2011, US spot gas prices briefly dropped below $\$ 3 /$ Mcf.

\section{Future gas prices}

The short term US gas price forecast (with seasonal swings in step with the demand cycle) is given in Fig. 8a. The baseline is set by the NYMEX gas future contracts, and the higher scenarios are by Deutsche Bank economists, projecting a median US gas price of 


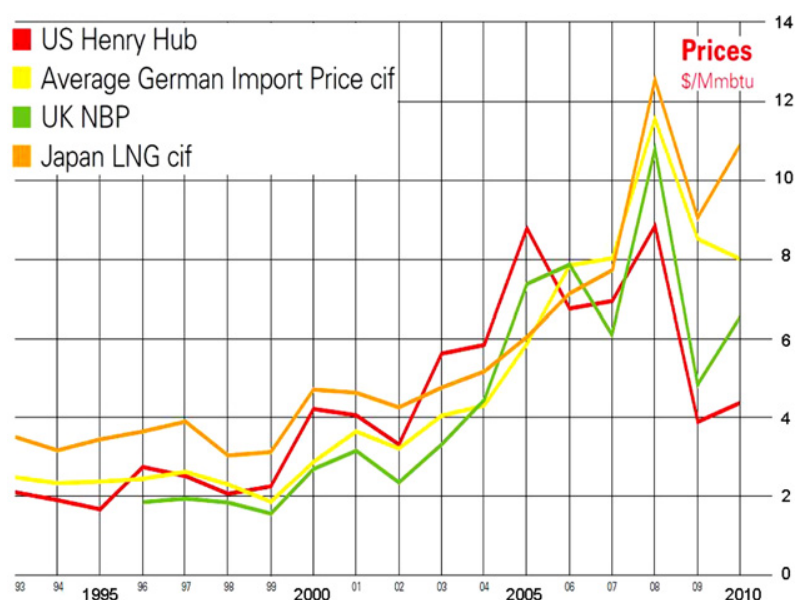

Fig. 7. Annually averaged prices for natural gas $(\$ / M m b t u \sim \$ / M c f)$ in the world's major gas markets [2].

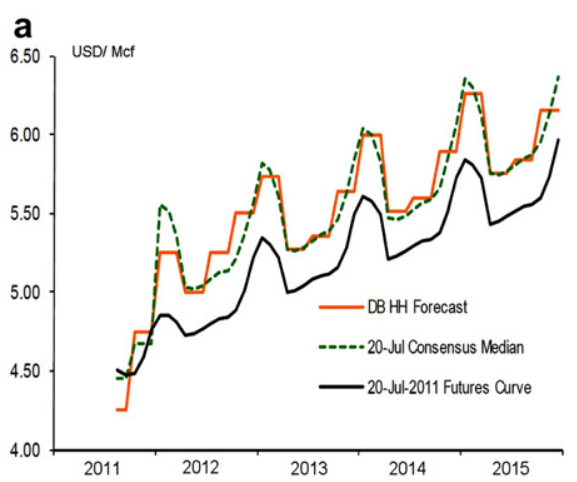

$\mathbf{b}_{\text {USD/Mot }}$

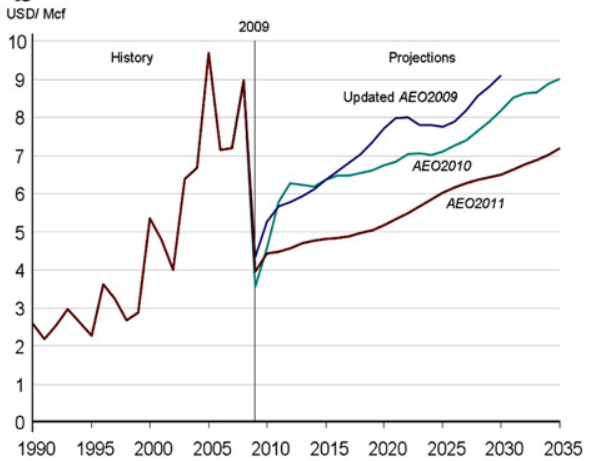

Fig. 8. a: Forward short-term price curve for US spot gas for the Henry Hub reference point based on NYMEX futures and slightly higher projections by the Deutsche Bank (Bloomberg Finance LP, NYMEX \& Deutsche Bank). b: US gas price projections (annual averages; real, inflation adjusted historic prices) according to 2009 long-term forward model by the Energy Information Administration [11,12]. The AEO 2011 model is the reference scenario.

\$6/Mcf by 2015 . Much more volatile price scenarios may unfold when production capacity is shut in if cash flow problems would lead to the demise of major shale gas players [10]. Fig. 8b shows the mid and long term US gas price scenarios by the US Energy Information Administration. The model assumes price pressure from shale gas production in a constrained North American gas market will keep US gas prices relatively low for the next few decades. This US gas price scenario sets a lower limit for gas prices in other world regions.

\section{Strategy conclusions}

Demand for gas continues to grow in all major gas markets. However, demand growth leads to a further decline of the reserve replacement ratio, unless technology innovations help to unlock the new unconventional gas reserves. Even assuming such unconventional gas will come on stream worldwide, Europe and Asia will compete for access to LNG and pipeline gas imports to fill an imminent gas supply gap. The consequent rise of natural gas prices in all world markets will help to make stranded gas in South America and Africa attractive exploration targets for E\&P companies. Countries in Europe and Asia with relative large percentages of natural gas in their primary energy mix should plan for cheaper alternatives to reduce dependency on gas importation as gas prices are set to rise further over the next decades.

\section{References}

[1] BP Statistical Review of World Energy, June 2011. www.bp.com/statisticalreview.

[2] BP Energy Outlook 2030, January 2011. http:// www.bp.com/liveassets/bp_internet/globalbp/ globalbp_uk_english/reports_and_publications/ statistical_energy_review_2011/STAGING/ local_assets/pdf/2030_energy_outlook_ booklet.pdf.

[3] R. Weijermars, Time for Europe to face oil and gas supply realities, First Break 29 (7) (2011) 43-46 (July Issue).

[4] DOE/EIA, Annual Energy Review 2009. Projections: National Energy Modeling System, run REF2011. D120810C (2009).

[5] DOE/EIA, Total reserves data RNGR11NUS_1a (2011).

[6] DOE/EAI, CBM reserves data RNGR51NUS_1 (2011).

[7] DOE/EIA, Shale gas reserves. Data RES EPGO R5301_NUS_BCF (2011).http://www.eia.gov/dnav /ng/ng_enr_shalegas_dcu_nus_a.htm.

[8] R. Weijermars, C. McCredie, Gas Pricing - Lifting the Price, Petroleum Review vol. 65 (No. 770) (2011) 14-17.

[9] R. Weijermars, Trans-Atlantic energy prices show need for realignment, Oil \& Gas Journal 109 (23) (2011) 26-33 (June 6 issue).

[10] R. Weijermars, Price scenarios may alter gas-to-oil strategy for US unconventionals, Oil \& Gas Journal 109 (1) (2011) 74-81.

[11] DOE/EIA [2010] Annual Energy Outlook, US Department of Energy, Energy Information Administration (2011).http://www.eia.doe.gov/ forecasts/aeo/executive_summary.cfm.

[12] EIA [2011] Short Term Energy Outlook, US Department of Energy, Energy Information Administration (August 2011). 